\title{
Home Countries and Transnational Bribery: China's Changing Approach
}

Ciprian N. Radavoi* \& Yongmin Bian ${ }^{* *}$

In 1999, Professor Philip Nichols argued that FCPA-style home country laws are efficient in combating transnational bribery, unlike host country regulation and corporate selfregulation. Observing feeble results obtained in 15 years of OECD Anti-bribery Convention, we find arguments for amending this assertion; home countries, aside from enforcing their own laws banning foreign bribery, should reconsider the classical ways of fighting transnational corruption, by helping host governments in their anti-corruption efforts and by encouraging their own corporations to join international dialogic webs. After presenting an original analysis of the reasons behind the limited impact of FCPA-style action, we would then further argue for the two alternative solutions backed by home states, looking respectively at the spectacular results of the anti-corruption campaign in Romania with US support, and at China's recent position that her corporations should adhere to international private standards on foreign bribery.

Keywords: Business Ethics, China, FCPA, International Bribery, OECD, Transnational Corruption.

* Lecturer in International Investment Law at the University of International Business and Economics (UIBE) Law School, Beijing, China; Member of Romanian Bar; Consul of Ministry of Foreign Affairs of Romania. LL.B. (Bucharest), LL.M. (Lund), Ph.D.(UIBE). ORCID: http:// orcid.org/0000-0002-9538-6019 The author may be contacted at: radavoi@uibe.edu.cn / Address: Shaoyaoju 2/13/1403, Chaoyang District, Beijing, P.R. China.

** Professor of Public International Law at the University of International Business and Economics (UIBE) Law school, Beijing, China. A.B./LL.M. (CUPL), Ph.D. (UIBE). ORCID: http://orcid. org/0000-0002-7950-1160. The author may be contacted at: bianyongmin@uibe.edu.cn / Address: 10 Huixin East Street, Chaoyang District, Beijing, 100029, P.R. China. 


\section{INTRODUCTION}

In 1999, when the OECD Convention on Combating Bribery of Foreign Officials in International Business Transactions (hereinafter OECD Anti-bribery Convention: "OABC") was entering into force, Professor Philip Nichols argued that globalization and fragmentation in the beginning of the millennium rendered home State action necessary for effectively combating transnational bribery, as host State action and corporate self-regulation had proven insufficient. ${ }^{1}$ As it often happens, reality later contradicts the initial optimism. In tackling the supply side of international bribery, home States have been rather modest since 1999. Therefore, host State and self-regulation should complement it. We, however, focus on the home State in our research, because the home State could, should and actually did support host State and corporate anti-corruption efforts.

In December 2014, the OECD released a 'ground-breaking' report on foreign bribery (hereinafter the Report), ${ }^{2}$ an analysis of data emerging from 427 enforcement actions - 263 individuals and 164 entities - resulting from the 207 cases since the entry into force of the OABC in 1999. The Report notes that the distribution of concluded foreign bribery cases per country is not proportionate to their respective importance as exporters and outward investors. ${ }^{3}$ The US, e.g., accounts for most of the cases (128), while other countries with an important share of world exports, like Australia, Mexico, Russia or Brazil, have not concluded even a single case. Transparency International already signaled this situation in $2011,{ }^{4}$ as twenty-one countries effected little or no enforcement.

Other data in the Report also seems to suggest that the OABC, trying to curb bribery in international transactions by targeting the supply side, does not work the way it was expected. Enforcement appears to have declined since 2011 in terms of criminal and monetary sanctions, and the average time taken to conclude foreign bribery cases has steadily increased over time, reaching an average of 7.3 years for the 42 cases concluded in 2013.5

According to the Transparency International's Bribe Payers Index ("BPI"), many parties of the $\mathrm{OABC}$ have not realized a bribery free world yet. On a scale of 0 to 10 (10 means that companies from that country never bribe abroad), the US ranks the 10th out of the 28 countries (8.1); Brazil stands 14th (7.7), and Mexico is 26th (7.0), with only China and Russia behind. The results are not too 
different from the previous editions of the Index. In fact, Canada and the UK have deteriorated 0.3 points in their index since 2008. The lack of progress reflected in BPI evidences weak implementation, empty rhetoric or double standards. ${ }^{7}$ In addition to the OECD Anti-bribery Convention, the UN Convention against Corruption ("UNCAC"), adopted in 2003, was criticized as an ineffective, expensive, and time-consuming option. ${ }^{8}$ Regarding the weak impact of the OABC and the UNCAC in curbing bribery, Weber and Getz observed that it would be naïve to expect full enforcement at national level with no self-enforceable international treaties.

Other analysts, however, have found that subsidiaries of multinational enterprises ("MNE") are less likely to encounter solicitations of bribes if their mother company is registered in a State party to the OABC. ${ }^{10}$ According to a study on the propensity of firms from thirty countries to engage in international bribery, MNEs from the OABC members are less likely to offer bribes. ${ }^{11}$ Another study shows that corruption in the host country would lead to relatively lower FDI in the OABC member countries. It means that the Convention would act as a deterrent to the corruption in foreign countries. ${ }^{12}$ Such a comprehensive analysis concludes that more cases of corruption have been punished since the adoption of the OABC. ${ }^{13}$ It is also believed that: "A widely disseminated, well-known and rigid anticorruption instrument such as the OECD Convention can indeed exert substantial influence on corrupt behavior, even beyond the OECD member states."

A positive aspect is that a uniform set of rules would significantly curtail corruption. ${ }^{15}$ Today, condemnation of corruption is a hypernorm; it is a universally accepted in principle but differently understood and applied around the world. Even in a narrower sense, all major economic players accept that bribing a foreign official has mostly something to do with an economic advantage, usually through a contract. As for the value-addition of moral and educational merits of international rules against bribing of foreign officials, it was argued that: "The primary significance of the anti-bribery convention lies ... in putting down a marker indicating that this kind of behavior is unacceptable." ${ }^{16}$ Businessmen everywhere already knew that it is wrong to bribe officials. Without enforceability and actual enforcement, those rules are just more pieces in the 'corruption paradox,' universally condemned yet universally present. ${ }^{17}$

Not all States have agreed on a single definition of corruption, which is 
perceived differently across the societies. However, "the word, bribery is clear and unmistakable." ${ }^{18}$ The OABC and the UNCAC provide very similar definitions of foreign bribery:

The promise, offering or giving to a foreign public official or an official of a public international organization, directly or indirectly, of an undue advantage, for the official himself or herself or another person or entity, in order that the official act or refrain from acting in the exercise of his or her official duties, in order to obtain or retain business or other undue advantage in relation to the conduct of international business. ${ }^{19}$

Intentionally to offer, promise or give any undue pecuniary or other advantage, whether directly or through intermediaries, to a foreign public official, for that official or for a third party, in order that the official act or refrain from acting in relation to the performance of official duties, in order to obtain or retain business or other improper advantage in the conduct of international business. ${ }^{20}$

As shown above, the world has a clear rule concerning one particular manifestation of corruption and this international rule was already absolved into the each municipal law by all the major capital exporting countries. All that is left is to enforce it.

In this research, the authors are primarily to bring to light various ways in which home States can contribute to the global desideratum of eliminating foreign bribery. In doing so, we will focus on models proposed by the two main economies of the world - the US and China. This research will underline the differences between the American approach which is based on institutional and informal support to host countries' anti-corruption efforts, and China's approach which is based on encouraging corporate self-regulation and participation of its multinationals in global anti-corruption policy networks. This paper is composed of six parts including short Introduction and Conclusion. Part two will discuss the theoretical grounds for the willingness of home countries to enforce anti-bribery laws. Part three will review the reasons why enforcement is difficult even for a State who is enthusiastically attempting it. This analysis will indicate solutions that are more suitable, in the real world, for mitigating the main disincentive to enforce laws against international bribery - the lack of guarantee that competing 
home States will enforce these laws in their turn. Then, two classical solutions will be suggested by case studies. Part IV will be a Romanian case study where it was decided that the home State should assist host States in strengthening anticorruption enforcement. Part V will analyze a Chinese case where the home State should guide its own corporations in resolving the issue privately, among themselves.

\section{How Willing are Home States to Enforce LAWS AGaINST OVERSEAS BRIBERY?}

All major economies except India are parties to either the OABC or the UNCAC prohibiting bribery of foreign officials. Although these Conventions require member States to adopt domestic laws preventing their corporations from bribing abroad, their success is still questionable. Transparency International has clearly stated that the main reason for poor enforcement is the lack of political will. ${ }^{21}$ Why are developed states quasi-unanimous in letting themselves be bound by an international obligation to domestically ban bribe offering to foreign officials, but most of them do so little to enforce it?

From the perspective of a host country, the dominant rationale for the anticorruption consensus has been economic, rather than normative. Here, corruption would hurt development by discouraging foreign investment, siphoning off funds or subjectively prioritizing projects to be publicly financed. ${ }^{22}$ From the perspective of the home country, it is a combination of material interest and moral values in successive stages of interaction. ${ }^{23}$ The 'interest' side here is mainly related to reputation. As it happens with other fields in which States acted or tried to act extraterritorially, the moral component is heavier. Schroth clearly expresses that: "At least in this particular way, [they] are not greatly exacerbating the misery of other countries." ${ }^{24}$ Or, in another inspired formulation: "Not in their backyards, either! ${ }^{25}$ It is fair to assume a preponderantly normative explanation of State adherence to international rules targeting the supply side of corruption.

These noble ideals, however, have not worked similarly in the regulations of home countries to control their corporations' overseas behavior in such fields as the environment, labor or human rights. ${ }^{26}$ In the US, a Bill for a Corporate Code 
of Conduct Act was introduced in the House of Representatives a few times from 2000 to 2006, but it was aborted. ${ }^{27}$ In Australia, a Corporate Code of Conduct Bill was rejected in a Senate Committee in 2000. ${ }^{28}$ In the UK, a similar Bill was introduced in 2004, but silently withdrawn soon afterward. ${ }^{29}$ In Canada, the Corporate Accountability of Mining, Oil and Gas Corporations in Developing Countries Act actually made it to final vote in 2009 , but was rejected by a small margin. ${ }^{30}$ In all these cases, the legislature's rationale for opposing this kind of law was the perceived damage they do to the competitive advantage of their own transnational corporations ("TNCs").

However, the law regulating overseas bribery would also do harm to corporations in the home country in their bid for contracts overseas. If following similar moral grounds and consensus is their necessity, why have the home countries been able to adopt laws on international bribery, but failed to regulate environmental or social harm? Theoretically, the latter would have had more chances of gathering 'Yes' votes, as social justice is a more emotionally charged issue.

This apparent paradox can be explained. Victims of crimes against environment or labor voice their concerns in the presence of the media. Photographs of the polluted river or the abused laborer would make the front page, whereas international bribery crimes become little known to the public. An essential element of bribery is secrecy; it happens behind closed doors between parties trusting each other to keep it secret, reducing the probabilities of getting caught. Significantly, 31 percent of the cases investigated under the OABC came to light due to self-reporting by companies, while only 3 percent was due to whistleblowing or report from the public. ${ }^{31}$ It is therefore not difficult to conclude that legislatures are more prone to extraterritorial anti-bribery legislation because these crimes are far more difficult to uncover, than those against the host country's environmental or human rights violations.

Another case is due to the home countries' lack of enthusiasm in enforcing these laws. It is a painful process of convincing them to criminalize foreign bribery. The US Foreign Corrupt Practices Act ("FCPA") was adopted in 1977 as a "unilateral initiative resulting from an upsurge in values around the Watergate scandal." 32 However, it took approximately two decades for Americans to convince their European and Asian partners (and economic rivals) to adopt similar 
measures. In the 1970s and the 1980s, the US initiatives for codes of conduct prohibiting bribery were rejected at the GATT and ECOSOC, specifically because of opposition by its western allies. ${ }^{33}$ Only later, in the 1990s, due to a series of bribery scandals, the US, supported by Transparency International, was able to persuade its European partners to adopt anti-bribery laws on a basic level. ${ }^{34} \mathrm{Up}$ until 1995, the EU Anti-bribery Convention had not been ratified. ${ }^{35}$ Finally as the World Bank declared the corruption as a cancer, ${ }^{36}$ the Inter-American Convention against Corruption and the OECD Anti-bribery Convention were concluded in 1996 and 1997, respectively.

The halfhearted adoption of anti-bribery laws in most OECD countries may be a ground for the disproportionate number of cases concluded, with the US accounting for almost 2/3 of the total, from 1999 until June 2014. ${ }^{37}$ If the OECD countries struggled so hard to resist the US pressures for adopting anti-bribery laws, one may legitimately question their genuine commitment to limiting their corporations' leeway abroad in the name of the anti-corruption values. But even assuming a true desire of a country's legislature to see all the bad corporate guys winning contracts abroad by bribing behind bars, this does not necessarily align with the enforcers' views, especially in the case of a law for extraterritorial use. In this vein, we should not forget that even in the US, the executive made several attempts to repeal or weaken the FCPA. ${ }^{38}$

This is mainly because the balance between values and interests functions differently in the legislative or the executive power. Perhaps we may look at the separation of power between the legislatures and the executive under democratic constitution. In the case of anti-bribery lawmaking, this was apparent in both the US and the EU, because they are more responsive to public pressure. However, numerous accountability gaps arise when the rules would make TNCs accountable to the general public through the government. ${ }^{39}$ The government has incentives to keep enforcement at bay in order to avoid damaging the corporations' comparative advantage, or out of fear that the TNCs would move their seats to another country. 


\section{Prosecuting the Supply Side of International BRIBERY}

\section{A. From the Regulators' Perspective}

Even the most committed country will face numerous challenges in enforcing the law against bribes to foreign officials. First, although there is consensus on incriminating bribery, the dichotomy of petty versus grand bribery affects efficiency of the law. Petty bribery - also called facilitating or lubricating payments would refer to "unofficial, improper, small payments made to a low level official to secure or expedite the performance of a routine or necessary action to which the payer of the facilitation payment is legally entitled." ${ }^{40}$ It is usually the result of extortion by low and mid-level officials driven by economic motivations. Actually, gift giving to public officials, entertainment or trips are largely accepted as general custom or business courtesies for marketing strategy in Asia and Africa. ${ }^{42}$ These forms of small bribes would not require any serious illegality to the officials. Big bribery, on the contrary, is paid to high level officials usually by companies desiring to win contracts in this way. ${ }^{43}$

As far as the $\mathrm{OABC}$ is concerned, the official commentaries clarify that facilitation payments are not made "to obtain or retain business," so that they are excluded from the Convention's scope. ${ }^{44}$ Similarly, FCPA excludes facilitation payments from its scope. ${ }^{45}$ Only the ICC rules reject the facilitation payments. ${ }^{46}$ The UN Convention does not make any clear reference to grease payments, although some scholars argue that the drafters had it in mind when referring to "any undue advantage" obtained by the corporation following the respective payment. ${ }^{47}$

Even if focusing only on grand bribery, ${ }^{48}$ a government cannot enforce the antibribery law easily, not just because gifts may hide actionable bribery, ${ }^{49}$ but also because a gray area exists between the two. In United States v. Vitusa Corporation, the defendant was prosecuted for a payment made to a government official toward expediting and securing the payment of a debt he was legally entitled to. ${ }^{50}$ The American policymakers and scholars argued for the establishment of a concrete dollar-limit for the clarification of the issue, ${ }^{51}$ while courts of the other OECD countries seem to resolve the problems in the gray area keeping account of their own culture. $^{52}$

Regarding the enforcement of the anti-bribery law, international comity and 
the host State's sovereignty would be also pose challenges to a government. Upon close inspection, priority cannot be accorded to comity in the extraterritorial application of anti-bribery laws. This is because only the TNC is the target of the enforcement action in terms of its nationality of the legislating State. Further, extraterritorial action is meant for the eradication of corruption, giving little ground for the host State to complain. ${ }^{53}$ Moreover, global agreement in the belief that "bribery is unethical" ${ }^{54}$ and its condemnation by all major religions ${ }^{55}$ overrides the challenges posed by comity.

In fact, host countries, or civil society in less developed host countries, may welcome this type of extraterritorial action by powerful countries. When Australian senators invoked comity and host country sovereignty to justify the rejection of the CSR Bill, ${ }^{56}$ e.g., a representative of Papua New Guinea-ahost country to much of Australian investment in mining - told the committee:

It would be very good if a corporate code of conduct was encouraged, so that Australian companies working in Papua New Guinea were able to do overseas what they practice in their own country, if our legislation is weaker than theirs. ${ }^{57}$

Another cause for which the home country government may impede enforcing the anti-bribery law may relate to material and organizational limitations. In fact, not all countries have such capability of extraterritorial reach like that of the US. Even the FCPA application offers numerous examples if prosecutors have failed to provide sufficient evidence. ${ }^{58}$ This is due to the "inherent and contrived complexity associated with the biggest abuses of organizational power." ${ }^{59}$ As TNCs are often registered in one country, seated in a second, and operating in a third, investigators would have difficulties in uncovering dishonest practices of TNCs. Aware of the illegality in bribing foreign officials, Corporations would bring their most significant resources to bear to conceal their acts, e.g., through convoluted routes for bribes, almost always using intermediaries ${ }^{60}$ and often passing many countries. ${ }^{61}$

\section{B. From the Duty Bearers' Perspective}

Extraterritorial laws targeting the supply side of transnational corruption are difficult not only to enforce, but also to obey. The pressure on corporations to 
disobey laws of their home country might be explained by the prisoners' dilemma or as an assurance problem; if no competitor acts corruptly, they will all be better off, but if only one will bribe the host country officials, he will get the pot while those who abide by the rules will suffer losses. ${ }^{62}$

Aside from this external dilemma, there is an internal, corporate governance dilemma stemming from cultural differences in dealing with corruption at home versus at the host country level. ${ }^{63}$ In this case, the main problem for a corporation is the willingness to play by the rules in connection with the disjuncture between the headquarters and its managers who effectively operate in the developing world. Here, bribes are often solicited by following unwritten norms, inherently absorbed by expat managers over time, or simply respected out of deference for local customs or fear of retaliation by unhappy officials.

The expat manager's cultural dissonance is so significant that it required a new theoretical tool to provide practical guidance in ethical decision-making. The Integrative Social Contract Theory requires managers to consider the impact of their decisions on relevant communities to evaluate whether the decision implicates non-controversial, universally accepted moral norms (hypernorms) simultaneously. ${ }^{64}$ This theory justifies the facilitation of payments, when they are accepted as local norms, since no hypernorm has emerged to condemn them. As for grand bribery intended to win a competitive bid, even if accepted in the local community, it should be rejected by the manager.

But scholars acknowledge that, due to the highly competitive nature of international business, it is increasingly difficult for field managers to remain ethical. ${ }^{65}$ Rather than experiencing moral dilemmas, they may simply assess the risk of being caught against the risk of missing a good contract. Among the three components of risk in business - risk perception, risk adjustment and risky choice ${ }^{66}$ only risk perception is related to a degree of permissiveness of the environment in which he operates; the adjustment may refer to attempts to conceal his acts, while the choice in the end may be dictated by a variety of factors, including personal characteristics of the manager.

Finally, the incongruence of values between the developed and the developing world, which may affect efficiency of foreign bribery laws, ${ }^{67}$ is visible not only in the developing, but also in developed countries like, e.g., the Netherlands, where almost half of top managers are foreigners. ${ }^{68}$ It is also significant that a large 
proportion of foreign managers in the $\mathrm{EU}$ are from the regions with a different

cultural approach to bribery, such as Africa, continental Europe, ${ }^{69}$ or Indians in the $\mathrm{UK}^{70}$

\section{Case of Romania: The Home State Supporting THE HOST COUNTRY's ANTI-CORRUPTION EFFORTS}

In his argument against the "leave-it-to-the-host-country" approach, Nichols saw problems in the long periods of transition experienced by developing countries and the very corrupted administrative system. ${ }^{71}$ His analysis applies like a glove to the situation of Romania in the 1990s, because there were so many corruption scandals in justice, government, local administration, education, police and the parliament. $^{72}$ Not surprisingly, Romania was then regarded as the most corrupted country in the EU. ${ }^{73}$

However, something has changed in the last few years. In June 2012, when former Prime Minister Adrian Nastase (2000-2004) was sentenced to four years in jail for taking bribes in office, many suspected it was a revenge of President Traian Basescu, a long term political opponent. Suspicions, however, lasted only for two years, because, in June 2014, the Anticorruption Directorate ("DNA"), arrested the President's brother for allegedly trafficking in his influence over the President. In 2014, the DNA prosecuted tens of MPs for corruption, together with several former ministers and some half of the so-called 'local barons' (the leaders of the 41 Romanian regional administrative divisions). ${ }^{74} 2014$ was celebrated as "The Year of Justice in Romania."

This change is related to our research in two ways. First, while targeting the receiving side, DNA has caught big fish from the supplying side of transnational bribery. In July 2014, the DNA prosecutors started hearing from dozens of current and former top dignitaries for a border security contract case relating to a European defense company, EADS. The contract was signed in 2004 and was in force until 2010. According to DNA, which also identified some middlemen and intermediary companies, "EADS paid in 2004, right after the contract was signed, a four-million euro advance that was to be used to bribe various people.", German Prosecutors investigating this case anticipated it to be the biggest case of 
transnational bribery in Europe. ${ }^{76}$ In another case also initiated in 2014, Microsoft and Fujitsu-Siemens are suspected of having bribed Romanian officials in order to secure State contracts. ${ }^{77}$ In this case, nine former Romanian ministers are currently charged by DNA concerning the preferential attribution of IT licenses.

Second, this case is connected to the existence of a powerful capital-exporting country behind Romanian anti-corruption institutions. A Romanian columnist referred to it as: "DNA under the American shield." ${ }^{, 78}$ Under this investigation, the US was a strong shield for DNA in $2014 .^{79}$

What brought the US to intervene this case? One is that the US was concerned about geopolitical and strategic aspects. After the Russian annexation of Crimea, Romania, a NATO country, found herself in the frontline of a very tense region and the US does not want it to be affected by corruption. The other is that the US desired to have fair economic competition for American investors in the country.

This aspect brings about one fallacy in Nichols' analysis. While acknowledging the minus effect of the home country approach - the firms from the country with anti-bribery law are less competitive than those from the countries without such prohibition - Nichols optimistically appreciated that this shortcoming would be mitigated when more home countries enact similar laws. ${ }^{80}$ As shown above, however, this was not always the case because, even if almost all the important home countries enact anti-bribery laws, the step from enactment to enforcement has so far proven to be too big.

Prisoner's dilemma functions differently at State level than at the company level. Ideally, all home States and their corporations are better off if all enact and enforce these laws. [Emphasis added] If just one of them reneges its commitment and turns a blind eye to her corporation winning contracts by bribing officials abroad, however, the honest competitors will be losers in the end. Reaching the ideal status in which respect for the rules is a long process of gradual improvement and mutual monitoring. The OECD Report 2014 has shown that there is still a long way to go. ${ }^{81}$

Powerful home States can use corruption cleansing efforts undertaken by host States which are beneficial for all parties. The host State can level the playing field for transnational competitors at least in that particular host State. For the host States, where "conjunctions of interests of political and economic power had turned the mechanism of acquiring of state power and its functioning into 
a commodity of corrupt transactions, ${ }^{, 82}$ the home State involvement would help achieve a purpose otherwise impossible. This effect is consistent with the missionary perspective on the UK Bribery Act 2010 as it was enforced "with a view to effecting an institutional change in the law and morality of other countries." ${ }^{83}$

This approach may have a problem, i.e., some internal forces would always claim that the home State action breaches international documents like the UN declaration prohibiting "interference in any form and for any reason whatsoever." In our case, the Romanian Orthodox Church harshly criticized American interference with Romania's internal affairs with a publication titled, "Who actually governs Romania?" ${ }^{85}$ Also, when the US acted similarly in Hungary, the Hungarian foreign minister expressed his government's "concern from the point of view of Hungary's sovereignty." " However, international law accommodates such interference, especially in the case of the fight against corruption. Interference is also acceptable at the level of political declarations if corruption is seen as a breach of human rights that may trigger developed countries' "responsibility to protect." ${ }^{87}$ It is even required by specific provisions on cooperation in international multilateral, regional and bilateral instruments.

\section{Case of China: The Home State Encouraging the Private Enforcement of Anticorruption RULES}

Home State initiatives described in the previous section were possible because the US needed Romania at the forefront of regional security. The home State (US) leveraged the host (Romania)'s need of economic partnership. ${ }^{88}$ None of these, however, would work with such a strong host State like China. In this case, another incentive may stir anticorruption for China: in the need of 'reputation' both internally and externally. Internally, China should address the corruption scandals involving top ranking officials. ${ }^{89}$ Externally, as a home State of large overseas investments, China is paying more attention to improve the behavior of her corporations in those fields like sustainable development ${ }^{90}$ and bribery of foreign officials. 
Since action against foreign bribery was initiated in 2011 with the Criminal Code amended, not a single case has been investigated yet. As shown above, however, important countries with similar provisions enacted long before are now in the same situation. In China, non-enforcement may not necessarily show a lack of willingness, but be explained by the flaws in relevant legal texts. Section XXIX of Article 164 of the 2011 Criminal Code provides that:

Whoever, for the purpose of seeking illegitimate commercial benefit, gives property to any foreign public official or official of an international public organization, shall be punished in accordance with the provisions of the preceding paragraph.

Article 164 of the PRC Criminal Law prohibited "giving money or property to any employee of a company or enterprise or other entity for the purpose of seeking illegitimate benefits." If the amount is "relatively large, ${ }^{91}$ violators "shall be sentenced to fixed-term imprisonment of not more than three years or criminal detention; if the amount involved is huge," the punishment is imprisonment for up to 10 years. ${ }^{92}$

The scope of foreign bribery defined by the OECD Anti-bribery Convention is broader and clearer than the Chinese one. For the OABC, offering advantage indirectly constitutes bribery, whereas the Chinese provision is silent on it. Also, 'advantage' is more than 'money' or 'property' in the OABC. It is not clear whether an act that is merely an 'offer' to give, but the bribe has not be given, constitutes bribery.

In these circumstances, China took a step forward in May 2014. A think tank related to Renmin University ("RDCY") and ICC China, supported by the Bank of China, delivered a report pushing the government and the overseas investors to fully embrace the ICC rules against corruption (hereinafter RDCY Report). ${ }^{93}$ The Report comments that reputation is an important motivation; frequent corruption scandals with Chinese overseas investments "damages the national image of China.". ${ }^{94}$

The RDCY Report aims to help Chinese managers "comprehend the conceptual differences about anti-corruption activities between China and the international business world," and to "provide a reference for decision-makers on establishing anti-corruption national systems for the Chinese government." 
It signifies a genuine desire of the third largest capital exporter (in terms of accumulated foreign direct investment) to play by the rules, as long as the others do it as well.

Both the ICC rules and the RDCY Report provide practical methods to deter bribery rather than claiming missionary aims of changing values in host countries. A level playing field is their target. The ICC rules state in the preface that "only a corruption-free system makes it possible for all participants to compete on a level playing field," while the RDCY Report acknowledges resolution of the 'prisoner's dilemma' as the main target of the ICC rules. ${ }^{96}$ In the attempt for seeking private resolution of the Prisoner's Dilemma by increasing transparency and mutual trust between international business companies, the Report addresses an important hurdle encountered by States when they try to resolve the problem by public law and policy: competitors are simply in a better position to monitor each other.

While the UNCAC has no monitoring mechanism and the OABC Working Group used to be overwhelmed by the huge area it should cover, the Chinese solution may achieve more efficiency, since corporations competing in the same field can easily keep their eyes on each other. A similar but sort of private/public chain of resolution was hoped for in 1999, with the adoption of the OABC:

With the adoption of the OECD Convention, multinational companies who have evidence that they lost business because of competitor bribery will be more likely to complain directly to prosecutors in the competitor's home country, with recourse to their own governments, the OECD Working Group, and the press, if the prosecutors fail to take action. Some will act as private attorneys general, aggressively rooting out evidence of competitors' bribery, using the Convention as a tool to right perceived competitive imbalances. ${ }^{97}$

Now, we know that this would not happen in reality, because corporations are not willing to transform themselves in "private attorneys general." Instead, they would rather internalize these problems within epistemic communities. These communities are defined as "networks of professionals with recognized expertise and competence in a particular domain and an authoritative claim to policy-relevant knowledge within that domain or issue-area." ${ }^{98}$ One example of an epistemic community is the one created around the ICC rules in the field of fighting bribery. ${ }^{99}$ That does not mean mere talks and knowledge-sharing; theories 
describe the interaction in these communities as 'complex interdependence" ${ }^{100}$ or 'regulatory webs ${ }^{101}$ convincingly explain the mechanisms leading to compliance with the community rules by factors like reputation, benefit sharing and reciprocal monitoring.

Take reputation for example. While the shameful behaviour of a corporation may indeed affect national image, ${ }^{102}$ it is difficult for the State to be responsible for an action undertaken by the corporation. ${ }^{103}$ If considering the ICC rules, things should be different. Damage to a reputation is full, direct and often irreparable. By pushing its corporations into this epistemic community, the RDCY Report advises China to silently resolve this pressing issue with others' hands. ${ }^{104}$ With a strong State-corporate connection, the government has little incentive to apply foreign bribery provision of the Criminal Code, but may choose to resolve the problem by mere adherence of its corporations to an epistemic community. Alternatively, in a different theoretical perspective applicable to the case, the government could place them under the ICC's umbrella as a 'mediating institution. ${ }^{105}$ Indeed, the ICC seems fit for this role, as "it is not just any community that fosters the desire to be ethical, but a small one - a mediating institution. In such a mediating institution, contracts are not based on consent alone, but have a socialized content - a banded contract." ${ }^{106}$

In addition, as the RDCY Report strongly emphasizes, the ICC rules are in fact enforceable, considering that the issuers intend to make a real change by having Chinese overseas investors adhere to them. The Report points out that the rules are "extensively adopted in business relations and are widely recognized in international arbitrations." ${ }^{107}$ It does not elaborate on them any further. With regard to the first aspect, the drafters probably had the following paragraph of the ICC Rules in mind:

\footnotetext{
An Enterprise should include in its contracts with Business Partners a provision allowing it to suspend or terminate the relationship, if it has a unilateral good faith concern that a Business Partner has acted in violation of applicable anticorruption law or of Part I of these Rules. ${ }^{108}$
}

A clause of this type, or more generally an ICC Anti-Corruption clause, ${ }^{109}$ may indeed prove to be helpful for judges and for the party claiming corruption in the enforcement of the ICC Rules in international arbitration. A mere "unilateral 
good faith concern" is more deterrent than a very high standard of proof - "clear and convincing evidence, ${ }^{110}$ - applied by the ICC tribunals in the absence of such clause.

The RDCY Report was the first in this series. Further analysis would include the so-called C2 ('Combating Corruption') principles, which emphasize the policies, procedures and publication. ${ }^{111}$ They may compliment the ICC rules, because, "whereas the ICC approach seems to aim for extreme simplicity, and therefore ease of application, the $\mathrm{C} 2$ anticorruption principles are more opentextured and theoretical." $" 112$ One future report will also discuss corruption under the ICSID arbitration, as recent evolutions may have an impact on Chinese overseas investors, who seem to have discovered the usefulness of the ICSID tool. ${ }^{113}$ In World Duty Free v. Kenya, ${ }^{114}$ the investor's claims were rejected because "claims based on contracts of corruption or on contracts obtained by corruption cannot be upheld." ${ }^{115}$ This arbitration award signals a changing approach to corruption at the $\operatorname{ICSID}^{116}$ of which Chinese investors should be aware.

\section{Conclusion}

This paper has analyzed the relative impotency of the public enforcement of rules against transnational bribery by the home State of the briber. We started from an analysis of the OECD Anti-bribery Convention by putting in balance three ways of fighting international corruption - home State, host State, and corporate action. Our research has found that the first one is the most effective and that it can take various forms, depending on the legal and cultural traditions of each home country. Additionally, we have demonstrated that the other two approaches, i.e., host State enforcement and corporate self-regulatory action, can also be revitalized with home State support. With regard to the host State, we would encourage the anticorruption efforts in Romania and more generally in the Eastern Europe by the US. As far as private enforcement is concerned, we brought to spotlight the initiative of a very influential Chinese institution to pressure Chinese overseas investors in adhering to the ICC anti-corruption rules.

The purpose of our research was not to overturn Nichols' theory, but to add to it. Home State indeed has a strong interest in an international market governed 
by fair competition. Home State has an interest to escape silently from enforcing the anti-bribery laws enacted under the international consensus that bribing is bad. Two approaches by Nichols - host State enforcement and private enforcement - address this problem. Host State's strong enforcement would indiscriminately target bribers from all countries. As for corporate self-enforcement, it may be more efficient in monitoring defections among competitors in a particular industry. Put differently, it makes more sense to resolve the prisoner's dilemma at the corporate level instead of at the State level.

For this research, we have taken Romania and China as examples of significant host and home countries, respectively. However, they are by no means general. Romania and China are rather unique in terms of geopolitical, economic, cultural, and historical circumstances. Not any host country would accept foreign interference at the degree seen in Romania; nor any home country exert an influence on its corporations to the degree of that of China. But if we lower the threshold, both assertions stand for all the host and home countries, respectively. Therefore, the uniqueness of the cases does not affect their illustrative character for our analysis.

In the war against the corruption, turning points are crucial, as they would signal the breaking away of unethical behavior. The anti-bribery case of Romania was not a creation of the US, but of the brave prosecutors in DNA. If foreign support was provided, we should place importance of EU institutions. The results of the Romanian case are unique in the history of Europe. In the Romanian public opinion, DNA has outranked even the Orthodox Church, ${ }^{117}$ which mainly checks cases of the incompatibility of officials. ${ }^{118}$

By pointing to the motivation of protecting its reputation and the following Chinese efforts to curb overseas corruption, we have also overlooked economic motivations. The RDCY Report mentioned that "corruption has become the biggest and most frequent obstacle encountered by Chinese investors overseas." 119 A changing attitude is visible and will prove to be beneficial. This Report finally comments that China tends to fight against corruption in campaigns rather than through a long-term and consistent approach. ${ }^{120}$ This approach can be a turning point on the way to corruption-free China. 


\section{REFERENCES}

1. P. Nichols, Regulating Transnational Bribery in Times of Globalization and Fragmentation, 24 Yale J. Int'L L. 257 (1999).

2. See OECD Foreign Bribery Report: An Analysis of the Crime of Bribery of Foreign Public Officials, available at http://dx.doi.org/10.1787/9789264226616-en (last visited on Feb. 10, 2016).

3. Id. at 31 .

4. Transparency International, Progress Report 2011: Enforcement of the OECD Anti-Bribery Convention (2011), available at http://www.transparency.org/whatwedo/publication/ progress_report_2011_enforcement_of_the_oecd_anti_bribery_convention (last visited on Feb. 11, 2016).

5. Supra note 2, at 14 .

6. Transparency International, Bribe Payers Index 2011, available at http://www.transparency. org/bpi2011 (last visited on Feb. 11, 2016).

7. M. Bukowanski, The Hollowness of Anti-Corruption Discourse, 13 REv. INT'L PoL. \& Ec. 181 (2006).

8. K. Pedigo \& V. Marshall, Bribery: Australian Managers' Experiences and Responses when Operating in International Markets, 87 J. Bus. Етнісs 59 (2009).

9. J. Weber \& K. Getz, Buy Bribes or Bye-Bye Bribes: The Future Status of Bribery in International Commerce, 14 Bus. Eтнісs Q. 695 (2004).

10. J. Spencer \& C. Gomez, MNEs and Corruption: The Impact of National Institutions and Subsidiary Strategy, 32 Strategic Mgmt. J. 300 (2011).

11. C. Baughn, N. Bodie, M. Buchanan \& M. Bixby, Bribery in International Business Transactions, 92 J. Bus. Eтнісs 15 (2010).

12. A. Cuervo-Cazura, Who Cares about Corruption?, 37 J. InT'L Bus. Stud. 807 (2006).

13. M. Cleveland, C. Favo, T. Frecka \& C. Owens, Trends in the International Fight against Bribery and Corruption, 90 J. Bus. Ethics 199 (2009).

14. J. Wouters, C. Ryngaert \& A. Cloots, The International Legal Framework against Corruption: Achievements and Challenges, 14 Melb. J. Int'L L. 229 (2013).

15. C. Pacini, J. Swingen \& H. Rogers, The Role of the OECD and EU Conventions in Combating Bribery of Foreign Public Officials, 37 J. Bus. Eтнісs 385 (2002).

16. R. Theobald, Should the payment of bribes overseas be made illegal?, 11 Bus. ETHICs EuR. Rev. 375 (2002).

17. D. Hess \& T. Dunfee, Fighting Corruption, a Principled Approach: The C2 Principles (Combating Corruption), 33 CoRnell InT'L L. J. 596 (2000).

18. Westacre Investments Inc. v. Jugoimport-SDPR Holdings Co., ICC Case No. 7047 (1994), available at http://www.trans-lex.org/207047 (last visited on Feb. 11, 2016).

19. UNCAC art. 16, $\uparrow 1$. 
20. OABC art. $1, \boldsymbol{\Phi} 1$.

21. Supra note 6.

22. Supra note 7, at 194. See also supra note 15, at 388-9.

23. K. Abbott \& D. Snidal, Values and Interests: International Legalization in the Fight against Corruption, 31 J. Legal Stud. 141 (2002).

24. P. Schroth, The United States and the International Bribery Conventions, 50 Ам. J. Comp. L. 621 (2002).

25. A. Neff, Not in Their Backyards, Either! Chicago Tribune, July 21, 1998, available at http:// articles.chicagotribune.com/1988-07-21/news/8801160480_1_environmental-protectionunion-car bide-pollution (last visited on Feb. 10, 2016).

26. Ciprian N. Radavoi \& Yongmin Bian, Enhancing the Accountability of Transnational Corporations: The Case for 'Decoupling' Environmental Issues, 16 EnvT'L. L. Rev. 168 (2014).

27. Id. at 176 .

28. The Australian Senate, Corporate Code of Conduct Bill 2000: Report of Corporations and Securities Committee, Procedural Text, of June 28, 2001, available at http://parlinfo.aph. gov.au/parlInfo/search/display/ display.w3p;adv=yes;orderBy=custom rank;page=0; query= corporate\%2Bcode\%2Bconduct;rec=9; resCount $=$ Default (last visited on Feb. 11, 2016).

29. Supra note 26, at 175.

30. L. Hill, Canadian lawmakers reject controversial Bill C-300, Mining WeEkLy, Nov. 5, 2010, available at http:/www.miningweekly.com/print-version/canadian-lawmakers-vote-downcontroversial-bill-c-300-2010-11-05 (last visited on Feb. 11, 2016).

31. Supra note 2, at 15.

32. Supra note 23, at 161.

33. S. Rubin, International Aspects of the Control of Illicit Payments, 9 Syracuse J. InT'L \& Comp. L. 321 (1982).

34. Supra note 23, at 161. See also supra note 24, at 610.

35. Supra note 24, at 611.

36. J. Wolfensohn, People and Development, Address to the Board of Governors at the Annual Meetings of the World Bank and the International Monetary Fund, reprinted in VOICE FOR the World's Poor: Selected Speeches and Writings of World Bank President James D. WolfEnsohn 1995-2005, 50 (World Bank, 1996), available at https://openknowledge. worldbank.org/bitstream/handle/10986/7304/343620PAPER0Vo101OFFICIAL0USE0ON LY1.pdf?sequence=1\&isAllowed=y (last visited on Feb. 11, 2016).

37. Supra note 2, at 31.

38. Supra note 23, at 162.

39. M. Koenig-Archibugi, Transnational Corporations and Public Accountability, 39 Gov. \& OpPosition 241-3 (2004).

40. ICC Rules on Combating Corruption 2011(ICC Rules) art. 6. 
41. Supra note 9, at 697.

42. N. Wallace-Bruce, Corruption and Competitiveness in Global Business - The Dawn of a New Era, 24 Melb. U. L. Rev. 357 (2000).

43. Id.

44. OECD Convention Commentaries, OECD Doc. DAFFE/IME/BR(97)20, 12 [4], art. 1, I 1, available at http://www.oecd.org/daf/anti-bribery/ConvCombatBribery_ENG.pdf (last visited on Feb. 11, 2016).

45. Supra note 14, at 239.

46. ICC Rules art. 6.

47. Supra note 14, at 239.

48. S. Salbu, Transnational Bribery: The Big Questions, 21 Nw. J. InT'L L. \& Bus. 435 (2001).

49. Supra note 1, at 295 (n. 212).

50. R. Koch, The Foreign Corrupt Practices Act: It's Time to Cut Back the Grease and Add Some Guidance, 28 B.C. InT'L \& Comp. L. Rev. 391 (2005).

51. Id. at 381-2.

52. This is inferred from the cases in South Korea and the Netherlands. See supra note 14, at 242-3.

53. P. Delaney, Transnational corruption: Regulation across borders, Discussion Paper on Policy and Governance at Asia Pacific School of Economics and Government (2005), available at http://unpan1.un.org/intradoc/groups/public/documents/APCITY/ UNPAN024516.pdf (last visited on Feb. 11, 2016).

54. T. Dunfee \& T. Donaldson, Untangling the corruption knot: global bribery viewed through the lens of integrative social contract theory, in The Blackwell Guide to Business Ethics 69 (N. Bowie ed., 2002).

55. Supra note 1, at 277.

56. Supra note 28.

57. Id.

58. M. Weismann, The Foreign Corrupt Practices Act: The Failure of the Self-Regulatory Model of Corporate Governance in the Global Business Environment, 88 J. Bus. Етнісs 615 (2009).

59. J. Braithwaite, On Speaking Softly and Carrying Big Sticks: Neglected Dimensions of a Republican Separation of Powers, 47 U. Toronto L. Rev. 325 (1997).

60. Intermediaries were used in three quarters of the cases concluded under the OECD convention. See supra note 2.

61. Supra note 53, at 30.

62. P. Nichols, Corruption as an Assurance Problem, 19 Am. U. InT'L L. Rev. 1307 (2004).

63. M. Darrough, The FCPA and the OECD Convention: Some Lessons from the U.S. Experience, 93 J. Bus. Eтнісs 257 (2010).

64. T. Donaldson \& T. Dunfee, Integrative Social Contracts Theory: A Communitarian 
Conception of Economics Ethics, 11 ECON. \& PHIL. 85 (1995).

65. K. Davidson, New Commandment: Ethics in All Marketing, 30 Marketing News 4 (1996).

66. K. MacCrimmon \& D. Wehrung, The Risk in-Basket, 57 J. Bus. 367 (1984).

67. M. Dalton, Efficiency v. Morality: The Codification of the Cultural Norms in the Foreign Corrupt Practices Act, 2 NYU J. L. \& Bus. 583 (2006).

68. K. van Veen \& I. Marsman, How International are Executive Boards of European MNCs? Nationality Diversity in 15 European Countries, 26 Eur. MGmt. J. 192 (2008).

69. Id. at 193.

70. K. van Veen, P. Rao Sahib \& E. Aangeenbrug, Where Do International Board Members Come From? Country-Level Antecedents of International Board Member Selection in European Boards, 23 InT'L Bus. Rev. 410 (2014).

71. Supra note 1, at 279-83.

72. L. Ilie, Romanian parliament boosts criminal immunity, may irk EU, ReUTERS, Jan. 22, 2013, available at http://www.reuters.com/article/2013/01/22/us-romania-politicsidUSBRE90L0PG20130122 (last visited on Feb. 11, 2016).

73. Transparency International, Corruption Perception Index 2014, available at https://www. transparency.org/cpi2014/results (last visited on Feb. 11, 2016).

74. For details, see Imparțialitate-Integritate·Eficiență [Impartiality · Integrity · Efficiency], DNA website, available at http://www.pna.ro/index.xhtml (last visited on Feb. 11, 2016).

75. See Romanian prosecutors start hearings in EADS corruption case, SofiA GLoBE, July 17, 2014, available at http://sofiaglobe.com/2014/07/14/romanian-prosecutors-start-hearings-ineads-corruption-case (last visited on Feb.11, 2016).

76. See Antena 3 (Romanian TV news channel with nationwide coverage), Dec 11, 2014, available at http://www.antena3.ro/romania/vlad-georgescu-despre-capetele-penale-aleafacerii-eads-mita-si-spaga-ajung-pana-in-varful-politic-276525.html (last visited on Feb. 11, 2016).

77. MA K., Whistleblower reveals "influence network" in Romania's acquisition of Microsoft licenses and IT hardware, CEE INSIGHT, Oct 3, 2014, available at http://www.ceeinsight. net/2014/10/03/whistleblower-reveals-influence-network-romanias-acquisition-microsoftlicenses-hardware (last visited on Feb. 11, 2016).

78. Ioana Ene Dogioiu, DNA sub scutul american antiPSD [DNA under US shield antiPSD] Ziare.com, Apr. 11, 2014, available at http://www.ziare.com/laura-codruta-kovesi/dna/dnasub-scutul-american-antipsd-1293172 (last visited on Feb. 11, 2016).

79. For details on the US' shielding the DNA in this case, see HotnEws, Jan. 8, 2014, available at http://www.hotnews.ro/stiri-esential-16367326-subsecretarul-stat-american-victorianuland-face-vizita-romania-pentru-discutii-despre-statul-drept.htm; The officlal website of the US Embassy to Romania, available at http://romania.usembassy.gov/policy/charge/pr04102014.html; WaLl St. Romania, June 26, 2014, available at http:/www.wall-street.ro/ articol/Politic/168147/duane-butcher-diplomat-sua-lupta-anticoruptie-este-reala-in-romania- 
arestarea-lui-mircea-basescu-o-demonstreaza.html; HotNews, Oct. 2, 2011, available at http://www.hotnews.ro/stiri-esential-18227080-victoria-nuland-discurs-dur-adresa-unorlideri-din-europa-centrala-protejati-parlamentarii-coruptii-ignorati-parlamentul-candconvine-cancerul-coruptiei-distruge-visele-celor-care-lupta-pentru-democra.htm; B. Novak, US Official Announces Anti-Corruption Initiative in Europe, BudAPEST BeAcon, Dec. 16, 2014, available at http://budapestbeacon.com/public-policy/us-official-announces-anticorruption-initiative-in-europe (all last visited on Feb. 11, 2016).

80. Supra note 1, at 289.

81. Supra note 2.

82. G. Vytautas, Corruption in the Context of International Economic Relations, in 3 Economics and Management: Current Issues and Perspectives 102 (2008).

83. Joseph Lee, Exclusivism, Inclusivism and Pluralism in the UK Bribery Act 2010: A UKTaiwan Anti-corporate Bribery Perspective, 12 J. Int'L Trade L. \& PoL'y 169 (2013).

84. UN Declaration on the Inadmissibility of Intervention and Interference in the Internal Affairs of States, G.A. Res. 36/103, U.N. Doc. A/RES/36/103 (Dec. 9, 1981), available at http:// www.un.org/documents/ga/res/36/a36r103.htm (last visited on Feb. 11, 2016).

85. See More and more openly: Who runs Romania, in fact? The chief of the Anti-corruption Directorate, glorified by the US Embassy, etc., Cuvantul Ortodox [The Orthodox Word], Apr. 12, 2014, available at http://www.cuvantul-ortodox.ro/recomandari/2014/04/12/ america-victoria-nuland-laura-kovesi-dna-amabasada-sua-mark-gitenstein-alegeriindependenta-justitiei-stat-drept-romania-infricosata (last visited on Feb. 11, 2016).

86. See US Anticorruption Plan, Reason for Concern, Daily News Hung., Dec. 16, 2014, available at http://dailynewshungary.com/us-anti-corruption-action-plan-reason-forconcern-says-szijjarto (last visited on Feb. 11, 2016).

87. Dept. of International Development, Corruption and Human Rights: Making the Connection. Versoix, Switzerland (2009), available at http://r4d.dfid.gov.uk/Output/185436 (last visited on Feb. 11, 2016).

88. Supra note 83.

89. B. Blanchard \& B. Kang Lim, China probes former senior aide to Hu Jintao over graft. REUTERS, Dec. 22, 2014, available at http://www.reuters.com/article/us-china-corruptionidUSKBN0K00WZ20141222 (last visited on Feb. 11, 2016).

90. Ciprian N. Radavoi \& Yongmin Bian, Why China Should Regulate Its Overseas Investors' Environmental Behavior, 5 BeIJING L. Rev. 22 (2014).

91. Vague formulations of this sort are also used in Article 389 of the Criminal Code, which governs the offence of official bribery generally.

92. PRC Criminal Law (amended as 2015) art. 164.

93. Research Group of International Conventions, Chongyang Institute for Financial Studies at Renmin University of China: Chinese Enterprises Going Global: Survey of International Anti-corruption Conventions (RDCY Report 中国人民大学重阳金融研究院国际惯例研究课题 
组), May 13, 2014, available at http://rdcy-sf.ruc.edu.cn/wap/displaynews.php?id=4569 (last visited on Feb. 11, 2016).

94. Id. at 6 .

95. Id.

96. Id. at 8 .

97. C. Corr \& J. Lawler, Damned If You Do, Damned If You Don't? The OECD Convention and the Globalization of Anti-Bribery Measures, 32 Vand. J. TRANSNAT'L L. 1299 (1999).

98. P. Haas, Introduction: Epistemic Communities and International Policy Coordination, 46 InT'L Org. 3 (1992). See also BritANNICA ENCyClopedia, available at http://www.britannica. com/topic/epistemic-community (last visited on Feb. 10, 2016).

99. It should be noted that ICC was the first institution to react to US call for action, as the Rules' first version was adopted almost concomitantly with the FCPA, in 1977.

100. R. Keohane \& J. Nye, Power and Interdependence (3d. ed. 2000).

101. J. Braithwaite \& P. Drahos, Global Business Regulation 550-63 (2000).

102. Supra note 90 , at $25-8$.

103. Supra note 53, at 25.

104. Id. at 24.

105. T. Fort \& J. Noone, Challenges to Corporate Governance: Banded Contracts, Mediating Institutions, and Corporate Governance: A Naturalist Analysis of Contractual Theories of the Firm, 62 L. \& Contemp. Probs. 163 (1999).

106. Id. at 196.

107. RDCY Report, at 8.

108. ICC Rules art. 3, ๆ E.

109. See ICC Anticorruption Clause 2012, available at http://www.iccwbo.org/AdvocacyCodes-and-Rules/Document-centre/2012/ICC-Anti-corruption-Clause (last visited on Feb. 11, 2016).

110. Westinghouse and Burns and Roe v. Nationall Power \& Co. and the Republic of Philippines, ICC Case No. 6401 (1991), available at http://www.trans-lex.org/133300 (last visited on Feb. 11, 2016).

111. Supra note 17.

112. Supra note 48, at 460.

113. Tza Yap Shum v. Republic of Peru, ICSID Case No. ARB/07/6 (Feb. 12, 2007), available at https://icsid.worldbank.org/apps/ICSIDWEB/cases/Pages/casedetail. aspx?CaseNo=ARB/07/6; Ping An v. Belgium, ICSID Case No. ARB/12/29 (Sept. 29, 2006), available at https://icsid.worldbank.org/apps/icsidweb/cases/Pages/casedetail. aspx? caseno=ARB/12/29 (all last visited on Feb 11, 2016)

114. World Duty Free Company Limited v. The Republic of Kenya, ICSID Case No. ARB/00/7, Award (Oct. 4, 2006), available at https://icsid.worldbank.org/apps/ICSIDWEB/cases/ Pages/casedetail.aspx?CaseNo=ARB/00/7; http:/www.italaw.com/documents/WDFv. 
KenyaAward.pdf (all last visited on Feb 11, 2016).

115. Id. $₫ 157$.

116. Tribunals until recently refused to entertain claims of corruption by one of the parties, let alone to invalidate a contract. See R. Bhojvwani, Deterring Global Bribery: Where Public and Private Enforcement Collide, 112 Colum. L. Rev. 76 (2012).

117. Further surveys will probably show a lower score for NAI, as the head of this 'integrity' agency was also arrested by DNA under corruption charges in March 2015.

118. See Sondaj INSCOP: ANI si DNA in topul increderii romanilor. Parlamentul si partidele politice in coada clasamentului [INSCOP Poll: ANI and DNA trust among Romans. Parliament and political parties in the bottom of the table], Revista 22, Oct. 23, 2014, available at http://www.revista22.ro/sondaj-inscop-ani-si-dna-in-topul-increderiiromanilor-parlamentul-si-partidele-politice-in-coada-clasamentului-49031.html (last visited on Feb. 10, 2016).

119. RDCY Report, at 5-6.

120. Id. at 7. 
